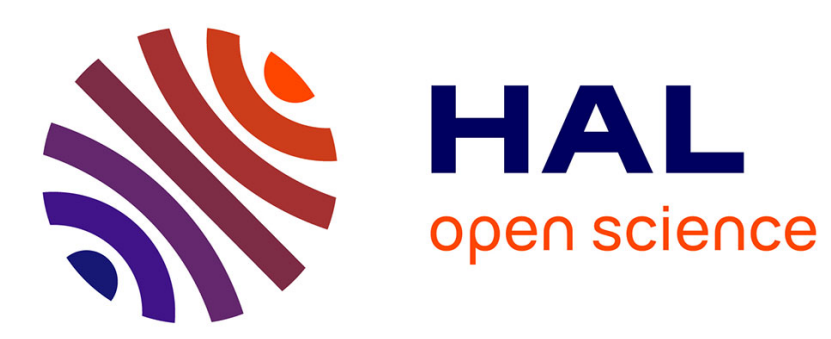

\title{
Does foreign aid increase private investment? Evidence from panel cointegration
}

\author{
Dierk Herzer, Michael Grimm
}

\section{To cite this version:}

Dierk Herzer, Michael Grimm. Does foreign aid increase private investment? Evidence from panel cointegration. Applied Economics, 2011, pp.1. 10.1080/00036846.2011.566183 . hal-00701864

\section{HAL Id: hal-00701864 \\ https://hal.science/hal-00701864}

Submitted on 27 May 2012

HAL is a multi-disciplinary open access archive for the deposit and dissemination of scientific research documents, whether they are published or not. The documents may come from teaching and research institutions in France or abroad, or from public or private research centers.
L'archive ouverte pluridisciplinaire HAL, est destinée au dépôt et à la diffusion de documents scientifiques de niveau recherche, publiés ou non, émanant des établissements d'enseignement et de recherche français ou étrangers, des laboratoires publics ou privés. 


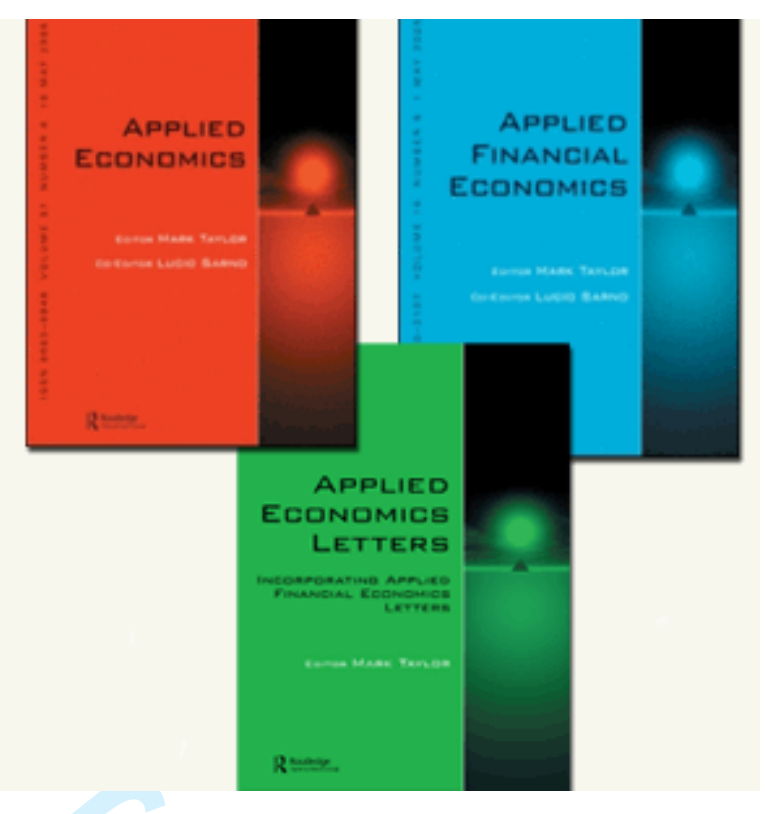

Does foreign aid increase private investment? Evidence from panel cointegration

\begin{tabular}{|c|c|}
\hline Journal: & Applied Economics \\
\hline Manuscript ID: & APE-2009-0113.R1 \\
\hline Journal Selection: & Applied Economics \\
\hline $\begin{array}{r}\text { Date Submitted by the } \\
\text { Author: }\end{array}$ & 07-May-2010 \\
\hline Complete List of Authors: & $\begin{array}{l}\text { Herzer, Dierk; Johann Wolfgang Goethe University, Chair of } \\
\text { Economic Development and Integration } \\
\text { Grimm, Michael; Institute of Social Studies }\end{array}$ \\
\hline JEL Code: & $\begin{array}{l}\text { F35 - Foreign Aid < F3 - International Finance < F - International } \\
\text { Economics, O16 - Financial Markets|Saving and Capital Investment } \\
<\text { O1 - Economic Development < O - Economic Development, } \\
\text { Technological Change, and Growth, C23 - Models with Panel Data < } \\
\text { C2 - Econometric Methods: Single Equation Models < C - } \\
\text { Mathematical and Quantitative Methods }\end{array}$ \\
\hline Keywords: & Foreign aid, Private investment, Panel cointegration \\
\hline
\end{tabular}




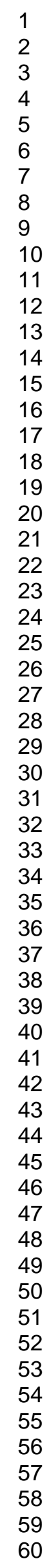

\section{S) ScholaroNE" \\ Manuscript Central}




\title{
Does foreign aid increase private investment? Evidence from panel cointegration
}

\author{
Dierk Herzer ${ }^{\mathrm{a},{ }^{*}}$ and Michael Grimm ${ }^{\mathrm{b}}$ \\ ${ }^{a}$ Johann Wolfgang Goethe-University, Grüneburgplatz 1, 60323 Frankfurt am Main, Germany \\ ${ }^{\mathrm{b}}$ International Institute of Social Studies, Erasmus University Rotterdam, Kortenaerkade 12, 2518 AX The \\ Hague, The Netherlands
}

This paper uses panel cointegration and causality techniques to examine the long-run relationship between foreign aid and private investment. Our main result is that aid has a statistically significant negative effect on private investment. This result is robust to outliers, different measures and forms of aid, sample selection, and the sample period. In addition, we find that long-run causality runs in both directions, suggesting that an increase in aid reduces private investment and that, in turn, higher private investment leads to lower aid inflows.

\section{Introduction}

The financing of aid is a key component of international development strategies. Developing countries, particularly the poorest, have insufficient domestic resources to finance their investment and development needs, while rich countries have, for various reasons (humanitarian, economic, and political), a desire to help countries that are less well off. Aid serves these purposes as rich donors provide concessional financing to poor recipients. The fundamental assumption underlying the allocation of aid is that it effectively contributes to economic growth and development in the recipient country. The

\footnotetext{
*Corresponding author. E-mail: DierkHerzer@wiwi.uni-frankfurt.de
} 
2002 Financing for Development Conference in Monterrey, Mexico and the 2005 G-8 Summit in Gleneagles, Scotland endorsed commitments by rich countries to increase the amount of foreign aid significantly, especially to Africa. Likewise, the Report of the Commission for Africa (2005) advocated a doubling of aid to Africa. These commitments are often reiterated, such as at the L'Aquila Summit in 2009. Thus, there is a political belief in the effectiveness of aid, although sceptics could counter that the plans are merely rhetorical, as the commitments have not yet been fully met.

The economics profession, on the other hand, is far more cautious than politicians in its conclusions about aid effectiveness. A considerable amount of empirical research since the 1970s has tested whether or not aid has a positive impact on economic growth in recipient countries, but without any consensus being reached. Studies such as Burnside and Dollar (2000, 2004) and Collier and Dollar (2004) find that aid per se has no effect on growth, although when interacted with policy, there is a conditional effect; aid has a positive impact on growth in countries with 'good' economic policies. Other studies such as those by Easterly et al. (2004) and Rajan and Subramanian (2008) suggest however that this result is not robust and, hence, make the argument that aid is insignificant, irrespective of economic policy. Still others, Dalgaard and Hansen (2001) and Daalgard et al. (2004), for example, find that aid has a positive effect on growth and that this effect is not conditional on economic policy.

Most of these studies in the tradition of Burnside and Dollar (2000) do not include investment in the estimated aid-growth relationship. If investment were to be included, the estimate of the growth-effect of aid would not account for those effects of aid operating through investment. Thus, an implicit assumption of all these studies is that the main effect of aid on economic growth is through investment (Gomanee et al., 2005). This assumption is also the basis of the Harrod-Domar-type models still used by international financial 
institutions to calculate aid requirements for target growth rates (Dalgaard and Erickson, 2009). Obviously, aid can affect overall investment by financing public investment (since aid is typically given to governments). However, not all aid is intended for investment, and not all investment is financed by aid (Herzer and Morrissey, 2009). Hence, an important question is, to what extent does aid affect private investment, particularly in the long run? This is the subject of the present paper.

The focus on private investment is interesting, since many studies suggest that private investment is associated with larger growth effects than is public investment (Khan and Reinhard, 1990; Greene and Villanueva, 1991; Dollar and Easterly, 1999; Devarajan et al., 2003). Consistently, Dollar and Easterly (1999) find that total investment is not a good predictor of growth in Africa. Moreover, Pritchett (1996) finds that high levels of public investment do not necessarily translate into higher levels of physical capital.

Despite the importance of this subject, there have been very few empirical studies investigating the effect of aid on private investment in the recipient country. The results of the few studies which have been done are mixed. Mosley et al. (1987), in a time-series study of eight countries, find that the private investment effect of aid is negative in one recipient country, statistically significant in three, and positive in four. Mahdavi (1990) uses cross-country data and finds a positive but insignificant association between aid and private investment. The pooled time-series cross-sectional regressions by Snyder (1996) suggest that aid has a statistically significant negative effect on private investment. Hadjimichael et al. (1995) investigate the impact of aid on private investment in a sample of Sub-Saharan African countries and find that the impact is positive for countries under structural adjustment and negative for countries with negative per-capita growth. Finally, Dollar and Easterly (1999) use a sample of 49 countries with up to six four-year periods. Employing pooled ordinary least squares (OLS) regressions, they find a positive effect of 
aid on private investment in a good economic policy environment, but this effect is subject to diminishing returns; the marginal impact of aid declines and becomes negative at high volumes of aid. If policies are poor, aid reduces private investment.

A limitation of all these studies, with the exception of Dollar and Easterly (1999), is that they do not adequately account for the potential endogeneity of aid, and this failure may bias the results. If, for example, donors are more willing to give aid to countries with high private investment rates, possibly because they believe that such countries use foreign aid more effectively, the results are biased towards a positive relationship between aid and private investment. If, in turn, donors prefer to provide aid to those countries in which private investment has declined-possibly due to factors such as natural disasters, economic shocks, or debt overhang-the results are biased towards a negative correlation between aid and private investment. Dollar and Easterly attempt to circumvent this problem by instrumenting aid through population and 'donors'-interest' variables. However, the quadratic aid-policy interaction term loses significance when instrumented. Moreover, the results seem to be sensitive to outliers, period length, and the exact definition of good economic policies.

A second problem is that, with the exception of Mosley et al. (1987), all studies use standard cross-sectional regression techniques. These techniques, however, are known to be unable to control for country-specific factors, and this inability gives rise to omittedvariable bias.

This paper examines the relationship between aid and private investment using panel cointegration and causality techniques to control for endogeneity and omittedvariable bias. Given that private investment is considered one of the main drivers of economic growth in developing countries, the paper contributes to the understanding of the mechanisms underlying the impact of aid on economic growth. Our results suggest that aid 
has a statistically significant negative effect on private investment, and that long-run causality runs in both directions, i.e., larger amounts of aid lead to lower private investment and higher levels of private investment lead to lower inflows of aid.

The remainder of this paper is organised into four sections. In Section II, we discuss the potential ways in which aid can affect private investment. Section III sets out the basic empirical model and describes the data. The econometric implementation and the estimation results are presented in Section IV, while Section V concludes.

\section{Theoretical Framework}

\section{The basic set up}

In what follows we present a theoretical framework that will guide our empirical analysis. It is well known that modelling investment behaviour of private firms is a serious challenge. Investment is the most volatile component of aggregate demand. Investment behaviour is a forward-looking activity with irreversible aspects and is driven by expectations, which are difficult to observe. As we will show below, the developingcountry context adds many other particularities that make it difficult to come up with a straightforward model of investment behaviour. For industrial countries much of the literature relies upon the 'flexible-accelerator approach' (Agénor and Montiel, 2008). The flexible-accelerator approach models investment as being mainly dependent upon expected aggregate demand, the cost of capital and labour, and the initial capital stock. Assuming the profit function

$$
\pi(k)=p y[k, n(w / p, k)]-w n(w / p, k)
$$


where $\pi$ are profits, $p$ is the price of output, $y$ is output, $k$ is capital stock, $w$ is the wage rate, and $n(\cdot)$ is the level of employment, derived from profit maximisation conditioned upon the existing capital stock, we find that the optimal capital stock $k^{*}$ must satisfy:

$$
\pi^{\prime}\left(k^{*}\right)=(\rho+\delta) p_{k}
$$

where $\rho$ is the discount rate, $\delta$ the rate of depreciation and $p_{k}$ the price of capital. The righthand side of Equation 2 reflects the user cost of capital.

Given an initial capital stock $k_{0}$, net investment in this model represents a gradual adjustment of the actual to the desired capital stock. Gross investment is derived by adding to this an amount of replacement investment that is proportional to the initial capital stock. Hence, relying on this type of model, a structural investment function needs to include expected future values of aggregate demand, the user cost of capital, the wage rate, and the initial stock of capital, which will all interact in a non-linear way. Since the above representation is static in the sense that it ignores short-run frictions (through short-run adjustment costs, for example), we adopt an empirical specification that captures the longrun relationship between aid and private investment. In doing so, we do not need to be concerned about the lags through which aid affects private investment. However, before we translate this model into a parsimonious empirical specification, we must discuss the aspects of the model that need to be adapted to fit the circumstances of a typical developing country (Rama, 1993; Servén and Solimano, 1993; Agénor and Montiel, 2008), and to form assumptions about how foreign aid may intervene in this context. 


\section{Developing country context and foreign aid}

First, in many developing countries, financial systems are only poorly developed and credit rationing may seriously affect the behaviour of private investment. Mlambo and Oshikoya (2001), for example, show that credit availability has a large effect on private investment in Africa.

Second, in developing countries a large share of capital goods is imported; thus, entrepreneurs will not only take into account the user cost of capital and the wage rate, but also the exchange rate and the availability of such goods. Obviously, in this case, a depreciation of the real exchange rate will have ambiguous effects on investment in exportoriented industries, since the depreciation would increase their competitiveness on the world market; but, at the same time, the industry would have to bear higher costs for imported capital goods. Which effect dominates will depend upon the structure of the particular firm. Foreign aid can in principle relax such foreign exchange constraints and may boost private investment by this mechanism. In other words, given that investment in developing countries generally depends strongly upon the foreign exchange available to import the capital goods necessary to expand production or to keep installed capacity functioning, aid may encourage private investment by relaxing foreign-exchange constraints.

Third, many developing countries suffered in the past from a serious debt overhang, which is seen by many as a factor, if not the main factor, inhibiting private investment, since it may imply confiscatory future taxation. Given that aid in recent years is often paid in the form of debt relief, aid may also boost private investment via this channel.

Fourth, macroeconomic instability, which is often induced by political instability, has been shown to be an important determinant of private investment (Rodrik, 1991; Aizenmann and Marion, 1993; Larrain and Vergara, 1993). Alesina and Tabellini (1989), 
in particular, illustrate analytically how political uncertainty may lead to a reduction in productive domestic investment in favour of capital flight and consumption. This implies that, in a context where aid helps to stabilise an economy, aid may again have positive effects on private investment. Guillaumont and Chauvet (2001) and Collier and Dehn (2001), for example, find that increased aid mitigates the adverse effects of external shocks, such as climatic shocks and trade shocks, on economic growth.

Fifth, given that developing countries typically have relatively high public investment rates, public investment is very likely to affect private investment through complementarity/substitutability relationships. Whether on balance public investment raises or lowers private investment is difficult to say. On the one hand, public sector investment can crowd out private investment expenditure if it uses scarce physical, human and financial resources that would otherwise be available to the private sector. On the other hand, public investment to maintain or expand infrastructure and the provision of public goods and services is likely to be complementary to private investment and may actually increase the productivity of capital invested by the private sector. Therefore, it is a priori unclear which effect will dominate. Bleaney and Greenaway (1993) and Ramirez (2000), for example, find a positive effect of public investment on private investment and attribute this effect to complementarities. Agénor et al. (2007) examine specifically the effect of public infrastructure investment on private investment in three countries-Egypt, Jordan, and Tunisia — using time-series analysis. They find that the effects are positive, but very small and short-lived. They explain these effects by the rather unfavourable environment for private investment in these three countries. Other studies, such as Nazmi and Ramirez (1997) and Mitra (2006), find clear evidence of crowding out. 
How does foreign aid intervene in the relationship between public and private investment? To answer this question, we assume for the moment that public investment, $I^{P u b}$, is financed by international aid, $A$, and domestic savings, $S$ :

$$
I^{P u b}=a A+\beta S
$$

where $\alpha$ and $\beta$ are the shares of foreign aid and domestic savings, respectively, that are used for public investment. Thus, not all aid finances public investment and not all public investment is financed by aid. Hence, Equation 3 shows that public investment is financed by foreign aid and domestic savings if $\alpha>0$ and $\beta>0$. From this, it follows that the share of domestic savings available for private investment is $(1-\beta)$ and that government consumption, $G$, can be written as the sum of the remaining part of aid and income, $R$ :

$$
G=(1-a) A+R
$$

According to Equation 3, a major channel through which aid can affect private investment is aid-financed public investment (if $\alpha>0$ ). Crowding-out effects occur when aid encourages the public sector to undertake investment projects that would otherwise be undertaken by the private sector, or when competition from aid-financed government projects for scarce resources, such as skilled labour, increases the costs facing private investors. If, on the other hand, foreign aid is used to finance public investment projects that would otherwise have been financed using scarce domestic financial resources, aid can eliminate a potential source of crowding out; $\beta$ would decline such that $\Delta A=-(\Delta \beta) S$. In addition, aid may generate positive externalities to private firms, thus stimulating private 
investment, if it is used to finance public investment in human and physical capital and in the economic infrastructure.

The inflow of aid may also create incentives for governments to relax their tax effort, a phenomenon that is widely recognized in the theoretical and empirical literature on the fiscal consequences of foreign aid (McGillivray and Morrissey, 2004). As a result, tax-financed public investment may be reduced. A weaker tax effort, in turn, reduces domestic distortions and transfers resources to the private sector (lower taxation means more income available for the private sector, implying that $(1-\beta)$ increases). This may then increase private sector investment.

However, it may also happen that aid is just used to increase government consumption, implying that $a=0$ so that $\Delta A=\Delta G$, according to Equation 4 . In this case aid just replaces domestic savings. This was an important argument against international aid put forward by the dependency school (Griffin, 1970; Weisskopf, 1972). Positive externalities of the type described above are generated only if aid does not substitute domestic savings, but instead finances additional public investment projects that would not have been undertaken without aid. Given that the literature on aid effectiveness largely concludes that aid is effective only under certain conditions, such as in the presence of good institutions and policies, and that aid has hardly made development miracles possible (although in most cases, economic growth would have been lower without aid [McGillivray et al., 2006]), one may expect that a substantial portion of aid is indeed consumed (Boone, 1996).

A sixth characteristic of developing countries is that institutions are often weak or non-existent. Institutions lower transaction costs by reducing uncertainty and establishing a stable economic structure to facilitate interactions, thus helping to allocate resources to their most efficient uses. Without institutions, individuals do not have incentives to invest 
in physical or human capital or adopt more efficient technologies, implying that resources are misallocated and private investment opportunities go unexploited. Thus, private investment is likely to depend strongly upon the quality of institutions, and aid may therefore affect private investment through its effects on institutions. The conventional argument is that by expanding a government's resource envelope, aid may reduce the government's need to explain its actions to citizens, which may in turn alleviate pressure on it to govern well. Poor governance is generally associated with a weakening of institutions necessary for a good investment climate, given that the government falters in its responsibilities to protect property rights, ensure a predictable judiciary, and limit corruption. The hypothesis of an aid-induced weakening of institutions is supported by several studies. Knack (2001) finds that higher aid levels erode the quality of governance; Bräutigam and Knack (2004) and Rajan and Subramanian (2007) suggest that aid is associated with weak governance, while Djankov et al. (2008) find that aid reduces the level of democratisation.

Similarly, it can be argued that aid can affect private investment if it encourages a diversion of resources from productive activities into unproductive rent seeking. More specifically, aid may induce self-interested individuals to engage in rent-seeking activities aimed at appropriating part of the resource windfall, and, as a result, scarce resources are withdrawn from other productive activities, as several theoretical models predict (Hodler, 2007; Economides et al., 2008). Rent-seeking may, in extreme cases, directly harm the economy by provoking civil conflicts. Such conflicts, of which war is the extreme example, affect the investment climate of a country in a number of ways, such as by generating uncertainty in the economic environment and/or by destroying the economic and political institutions and infrastructure that facilitate an efficient allocation of resources. Maren (1997), for example, argues that Somalia's civil war was caused by the 
desire of different factions to control the large amount of food aid the country was receiving.

In summary, aid may stimulate private investment by relaxing foreign exchange constraints (thus reducing $p_{k}$ ), reducing the debt overhang, and increasing macro-economic stability (this should raise positive expectations among entrepreneurs). In addition, and perhaps most importantly, if aid is used by the recipient government to finance public investment in education, research and development, and physical infrastructure, such investment may generate positive externalities for the private sector and thus increase the productivity of private investment (by raising $\pi^{\prime}$ ). Aid may also eliminate a possible source of crowding out if it is used to finance public investment projects that would otherwise have been financed using scarce domestic financial resources ( $p_{k}$ declines). In addition, foreign aid can be used to reduce taxes, thereby reducing distortions in the economy and increasing the income of the private sector, which may then have a similar positive effect on private investment (by reducing $p_{k}$ ). However, the other side of the coin is that foreign aid may reduce private investment when the recipient government uses the aid to finance investment projects that would otherwise be undertaken by the private sector. Crowding-out effects may also occur when aid-financed public investment competes with private investment for scarce resources, such as skilled labour. Finally, high levels of aid over long periods of time can have substantial negative effects on private investment by weakening institutions and encouraging rent-seeking activities.

Thus, aid can affect private investment in several ways, perhaps the most important of which is aid-financed public investment. From this, it follows that the net effect of aid is theoretically ambiguous and becomes an empirical question. Although our objective is to examine the long-run relationship between aid and private investment in detail, we have to admit that the available data do not adequately allow identification of the exact channels 
through which aid affects private investment. Our focus is thus primarily on the net longrun effect, which we will investigate using estimation techniques that are robust (under cointegration) to a variety of estimation problems, such as omitted variables and endogeneity; to our knowledge these techniques have not been used thus far in the existing literature. Moreover, we analyse whether aid-financed public investment crowds in or crowds out private investment.

\section{Model and Data}

The analysis will examine the long-run relationship between aid and private investment. In this section, we present the basic empirical model, discuss some econometric issues, and describe the data.

Following common practice in panel cointegration studies (Drine and Rault, 2003; Herzer, 2008a; Crowder and de Jong, 2010), we consider a bivariate long-run relationship of the form

$$
I_{i t}=a_{i}+\delta_{i} t+\beta A_{i t}+\varepsilon_{i t}
$$

where $I_{i t}$ is the private-investment-to-GDP ratio over time periods $t=1,2, \ldots, T$ and countries $i=1,2, \ldots, N$, and $A_{i t}$ is represented by the standard measure of aid-the percentage share of net Official Development Assistance (ODA) in GDP. The coefficient $\beta$ can be interpreted as the long-run elasticity of private investment with respect to aid, measuring the net long-run effect of aid on private investment. As the principal interest is on the long-run effect, it is not essential to be concerned about the variable lags through which aid will impact private investment (as discussed in Section II). Finally, any country- 
specific omitted factors which are relatively stable in the long run or which evolve smoothly over time are captured by country-specific fixed effects, $a_{i}$, and country-specific time trends, $\delta_{i} t$

Equation 5 assumes a long-run bivariate relationship between permanent movements in the aid-to-GDP ratio and permanent movements in the private-investmentto-GDP ratio. Necessary conditions for this assumption to hold, and thus for our model to be a correct description of the data, are that both the individual time series for aid (relative to GDP) and the individual time-series private investment (relative to GDP) are nonstationary or, more specifically, integrated of the same order, and that $I_{i t}$ and $A_{i t}$ form a cointegrated pair. A regression consisting of two cointegrated variables has a stationary error term, $\varepsilon_{i t}$, in turn implying that no relevant integrated variables are omitted; any omitted nonstationary variable that is part of the cointegrating relationship would enter the error term, thereby producing nonstationary residuals and thus leading to a failure to detect cointegration. If, on the other hand, cointegration between a set of variables is detected, this same stationary relationship will also be found in an enlarged variable set (Johansen, 2000).

Another assumption underlying Equation 5 is that private investment is endogenous in the sense that, in the long run, changes in aid cause changes in private investment. However, although the existence of cointegation implies long-run Granger causality in at least one direction, long-run causality may also run from private investment to aid, as discussed in the beginning of this paper. The empirical implication is that it is not only crucial to examine the integration and cointegration properties of the variables, but it is also important to deal with this endogeneity problem and to investigate the direction of causality. 
The data on private investment as a percentage of GDP are from the International Finance Corporation (IFC)'s Trends in Private Investment in Developing Countries: Statistics for 1970-2000, authored by Everhart and Sumlinski (2001). The data on aid come from the World Development Indicators of the World Bank. Since the World Development Indicators do not report data on net ODA as a percentage of GDP, we calculate the aid-toGDP ratio by multiplying ODA per capita (in current US dollars) by population, divided by GDP (in current US dollars). ODA consists of net disbursements of loans and grants made on concessional terms by official agencies of the members of the Development Assistance Committee (DAC) and certain Arab countries to promote economic development and welfare in recipient countries listed as developing by the DAC. However, although the DAC collects and reports only non-military grant and low-interest loan assistance to developing countries, this standard measure has limitations. For example, it also includes non-financial aid in the form of technical assistance, which may contribute to capacity building and aggregate productivity (although much of this aid is actually spent in the donor, rather than the recipient, country) and food aid (which could be considered as investment in human capital in the broadest sense). Since these two types of aid might not directly affect private investment, we use a second measure of aid to check the robustness of our results: net ODA, excluding technical cooperation and food aid, $A_{i t}^{\text {Financial }}$. The data on $A_{i t}^{\text {Financial }}$ are from the International Development Statistics 2010 CD-ROM, published by the OECD.

The fundamental problem, however, is that ODA does not identify the aid used for public investment; the coefficient on $A_{i t}$ captures the (net) effect of total aid and thus not necessarily the effect of aid-financed public investment on private investment. To explicitly test whether public investment financed by aid crowds in or crowds out private investment, we construct a third measure of aid: We regress public investment (from the 
IFC's Trends in Private Investment in Developing Countries) on aid for each individual country, $I_{i t}^{P u b}=b_{i} A_{i t}+\xi_{i t}$. The estimated residuals, $\hat{\xi}_{i t}$, from this regressions represent the part of public investment that is not attributed to aid. Then, we subtract $\hat{\xi}_{i t}$ from $I_{i t}^{P u b}$ to obtain that part of public investment that is financed by aid, $A_{i t}^{\text {Invested }}$. The difference between $A_{i t}$ and $A_{i t}^{\text {Invested }}$ is, in turn, a measure of consumed aid, $A_{i t}^{\text {Consumed }}$, which will also be considered in the next section. As shown by Pagan (1984), the use of such generated regressors produces asymptotically efficient estimates and the correct values for the standard errors.

The identification and estimation of cointegrating relationships requires the use of data over a sufficiently long period of time. Since a period of 30 years should be long enough for this purpose, we select a sample of countries for which continuous data are available over a 30-year period from 1970 to 1999. This sample selection results in a balanced panel of 540 observations on 18 countries: Argentina, Brazil, Chile, Colombia, the Dominican Republic, Ecuador, El Salvador, Guatemala, India, Kenya, Malaysia, Mexico, Pakistan, Paraguay, Thailand, Tunisia, Turkey, and Uruguay. Obviously, this is not a random sample of aid recipients. For example, it does not include any countries from Sub-Saharan Africa, except Kenya. Moreover, most of the countries in the sample are currently relatively stable politically, and almost all have well-developed institutions and a well-performing private sector. They also receive less aid, as measured by its share of GDP, than the average aid recipient, among other things, because many of these countries have good access to international capital markets.

Therefore, we provide an additional robustness check by using a second sample with 585 observations on 39 countries over the period from 1985 to 1999 . Admittedly, this period is possibly too short to capture the long-run relationship between aid and private investment. Given, however, that panel cointegration methods can be implemented with 
shorter data spans than their time-series counterparts (due to exploitation of both the timeseries and cross-sectional dimensions of the data), the use of this short sample period should not seriously affect the results. Of the countries in this sample, Malawi is the most aid-dependent economy, with aid amounting to more than 24 percent of GDP on average in the period from 1985 to 1999, followed by Madagascar, Dominica, Haiti, Kenya, Grenada, Belize, El Salvador, Egypt, and St. Lucia. All these countries have an average ratio of aid to GDP of more than five percent. In Argentina, Barbados, Brazil, Chile, China, Colombia, India, Malaysia, Mexico, Panama, South Korea, Thailand, Trinidad and Tobago, Turkey, Uruguay, and Venezuela, aid accounts for less than one percent of GDP, while in Bangladesh, the Dominican Republic, Ecuador, Guatemala, Indonesia, Mauritius, Morocco, Namibia, Pakistan, Paraguay, Peru, the Philippines, and Tunisia, the aid-to-GDP ratio is between one and five percent. To also test whether there are significant differences in the effects of aid on private investment between highly aid-dependent countries, moderately aid-dependent countries, and minimally aid-dependent countries, we will divide the sample into three sub-samples: countries with aid inflows above five percent of GDP, countries with aid-to-GDP ratios between one and five percent, and countries with aid inflows below 0.1 percent.

\section{Empirical Analysis}

This section examines the long-run impact of aid on private investment. Specifically, we use panel data techniques that allow us to control for omitted-variable and endogeneity bias. We begin this section by first examining the basic time-series properties of the data. Then, we test for the existence of a long-run or cointegrating relationship between $A_{i t}$ and 
$I_{i t}$. Thereafter, we estimate this relationship and examine the robustness of the results. Finally, we test the direction of causality between the two variables.

\section{Time series properties}

To examine the time-series properties of the data, we use the panel unit root test of Im, Pesaran, and Shin (2003) (IPS), which is based on the augmented Dickey-Fuller (ADF) regression for the $i$ th cross-section unit:

$$
\Delta x_{i t}=z_{i t}^{\prime} \gamma+\rho_{i} x_{i t-1}+\sum_{j=1}^{p_{i}} \varphi_{i j} \Delta x_{i t-j}+\varepsilon_{i t}
$$

where $p_{i}$ is the lag order and $z_{i t}$ represents deterministic terms, such as fixed effects or fixed effects combined with individual time trends. The IPS test tests the null hypothesis of a unit root for all $i, H_{0}: \rho_{i}=0$, against the alternative of (trend) stationary, $H_{1}: \rho_{i}<0, i=1$, $2, \ldots, N_{1} ; \rho_{i}=0, i=N_{1}+1, N_{1}+2, \ldots, N$, using the standardised $t$-bar or IPS statistic

$$
\Gamma_{\bar{t}}=\frac{\sqrt{N}\left[\bar{t}_{N T}-\mu\right]}{\sqrt{v}}
$$

where $\bar{t}_{N T}$ is the average of the $N=18$ cross-sectional ADF $t$-statistics, and $\mu$ and $v$ are, respectively, the mean and variance of the average of the individual $t$-statistics, tabulated by Im et al. (2003).

However, the standard IPS test can lead to spurious inferences if the errors, $\varepsilon_{i t}$, are not independent across $i$, for example, due to common shocks or spillovers between countries. Therefore, we also employ the cross-sectionally augmented IPS test proposed by 
Pesaran (2007), which is designed to filter out the cross-section dependency by augmenting the ADF regression with the cross-section averages of lagged levels and firstdifferences of the individual series. Accordingly, the cross-sectionally augmented ADF $(\mathrm{CADF})$ regression is given by

$$
\Delta x_{i t}=z_{i t}{ }^{\prime} \gamma+\rho_{i} x_{i t-1}+\sum_{j=1}^{p_{i}} \varphi_{i j} \Delta x_{i t-j}+\alpha_{i} \bar{x}_{t-1}+\sum_{j=0}^{p_{i}} \eta_{i j} \Delta \bar{x}_{t-j}+v_{i t}
$$

where $\bar{x}_{t}$ is the cross-section mean of $x_{i t}, \bar{x}_{t}=N^{-1} \sum_{i=1}^{N} x_{i t}$. The cross-sectionally augmented IPS statistic is the simple average of the individual CADF statistics and is defined as

$$
C I P S=t-\mathrm{bar}=N^{-1} \sum_{i=1}^{N_{i}} t_{i}
$$

where $t_{i}$ is the OLS $t$-ratio of $\rho_{i}$ in Equation 8. Critical values are tabulated by Pesaran (2007).

The test results for the variables in levels and in first differences are presented in Table 1. Both the IPS and the CIPS test statistics are unable to reject the hypothesis that all countries have a unit root in levels. Since the unit root hypothesis can be clearly rejected for the first differences, we conclude that $I_{i t}$ and $A_{i t}$ are integrated of order $1, \mathrm{I}(1)$ - the necessary condition for cointegration in a bivariate context. Thus, the next step in our analysis is an investigation of the cointegration properties of the variables.

[Table 1 about here] 


\section{Cointegration tests}

We first test for cointegration using the Larsson et al. (2001) approach, which is based on Johansen's (1988) maximum likelihood estimation procedure. Like the Johansen time series cointegration test, the Larsson et al. panel test treats all variables as potentially endogenous, thus avoiding the normalization problems inherent to residual-based cointegration tests. It involves estimating the Johansen vector error correction model for each country separately and then computing the individual trace statistics $\operatorname{LR}_{i T}\{H(r) \mid H(p)\}$. The null hypothesis is that all countries have the same number of cointegrating vectors $r_{i}$ among the $p$ variables $H_{0}: \operatorname{rank}\left(\Pi_{i}\right)=r_{i} \leq r$, and the alternative hypothesis is $H_{1}: \operatorname{rank}\left(\Pi_{i}\right)=p$, for all $i=1, \ldots, N$, where $\Pi_{i}$ is the long-run matrix of order $p \times p$. To test $H_{0}$ against $H_{1}$, a panel cointegration rank trace test is constructed by calculating the average of the $N$ individual trace statistics by

$$
\overline{L R}_{N T}\{H(r) \mid H(p)\}=\frac{1}{N} \sum_{i=1}^{N} L R_{i T}\{H(r) \mid H(p)\}
$$

and then standardising it as follows:

$$
\Psi_{\overline{L R}}\{H(r) \mid H(p)\}=\frac{\sqrt{N}\left(\overline{L R}_{N T}\{H(r) \mid H(p)\}-E\left(Z_{k}\right)\right)}{\sqrt{\operatorname{Var}\left(Z_{k}\right)}} \Rightarrow N(0,1)
$$

where the mean, $E\left(Z_{k}\right)$, and variance, $\operatorname{Var}\left(Z_{k}\right)$, of the asymptotic trace statistic are tabulated by Breitung (2005) for the model we use (the model with a constant and a trend in the cointegrating relationship). As shown by Larsson et al. (2001), the standardized panel trace statistic has an asymptotic standard normal distribution as $N$ and $T \rightarrow \infty$. 
In addition, we compute the Fisher statistic proposed by Madalla and Wu (1999), which is defined as

$$
\lambda=-2 \sum_{i}^{N} \log \left(p_{i}\right)
$$

where $p_{i}$ is the $p$-value of the trace statistic for country $i$, calculated from the response surface estimates in MacKinnon et al. (1999). The Fisher statistic is distributed as $\chi^{2}$ with $2 \times N$ degrees of freedom.

However, these test procedures do not take into account potential error crosssectional dependence, which could bias the results. To test for cointegration in the presence of possible cross-sectional dependence we follow Holly et al. (2010) and adopt a residualbased two-step approach in the style of Pedroni (1999). But unlike Pedroni, we use the common correlated effects (CCE) estimation procedure developed by Pesaran (2006) in the first-step regression. This procedure allows for cross-sectional dependencies that potentially arise from multiple unobserved common factors by augmenting the cointegrating regression with the cross-sectional averages of the dependent variable and the observed regressors as proxies for the unobserved factors. Accordingly, the crosssectionally augmented cointegrating regression we estimate for each country is given by

$$
I_{i t}=a_{i}+\delta_{i} t+\beta_{i} A_{i t}+g_{i 0} \overline{A_{t}}+g_{i 1} \overline{I_{t}}+e_{i t}
$$

where $\overline{I_{t}}$ and $\overline{A_{t}}$ are the cross-sectional averages of $I_{i t}$ and $A_{i t}$ in year $t$. In the second step, we compute the cross-sectionally augmented IPS statistic for the residuals from the individual CCE long-run relations, $\hat{\mu}_{i t}=I_{i t}-\hat{\delta}_{i} t-\hat{\beta}_{i t} A_{i t}$, including an intercept. Thus, we 
account for unobserved common factors that could be correlated with the observed regressors in both steps.

The results of these tests are presented in Table 2. For completeness, we also report the standard panel and group ADF test statistics suggested by Pedroni (1999). As can be seen, all tests strongly suggest that $I_{i t}$ and $A_{i t}$ are cointegrated. The standardized trace statistics and the Fisher $\chi^{2}$ statistics clearly support the presence of one cointegrating vector. Also, the CIPS, the panel ADF, and the group ADF statistics reject the null hypothesis of no cointegration at least at the five percent level, implying that there exists a long-run relationship between aid and private investment.

\section{[Table 2 about here]}

\section{The long-run relationship between aid and private investment}

Having tested for cointegration, the next step of the analysis is to estimate the long-run effect of aid on private investment - the parameter $\beta$ in Equation 5. To this end, we use the within-dimension panel DOLS estimator suggested by Kao and Chiang (2000). The DOLS regression in our case is given by

$$
I_{i t}=a_{i}+\delta_{i} t+\beta A_{i t}+\sum_{j=-p}^{p} \Phi_{i j} \Delta A_{i t-j}+\varepsilon_{i t}
$$

where $\Phi_{i j}$ are coefficients of current, lead, and lag differences, which account for possible serial correlation and endogeneity of the regressor(s), thereby yielding unbiased estimates. Thus, an important feature of the DOLS procedure is that it generates unbiased estimates for variables that cointegrate even with endogenous regressors. Consequently, in contrast to cross-sectional and conventional panel approaches, this approach does not require 
exogeneity assumptions nor does it require the use of instruments. In addition, the (panel) DOLS estimator is superconsistent under cointegration, and is robust to the omission of variables that do not form part of the cointegrating relationship.

In Table 3 we present panel DOLS point estimates of the long-run effect of aid on private investment for the raw data as well as for data that have been demeaned over the cross-sectional dimension (i.e., in place of $I_{i t}$ and $A_{i t}$, we use $I_{i t}^{\prime}=I_{i t}-\overline{I_{t}}, A_{i t}^{\prime}=A_{i t}-\overline{A_{t}}$, where $\overline{I_{t}}=N^{-1} \sum_{i=1}^{N} I_{i t}$ and $\overline{A_{t}}=N^{-1} \sum_{i=1}^{N} A_{i t}$ ). The latter allows us to account for potential cross-sectional dependence through common time effects. As can be seen, the results for both the unadjusted and the demeaned data show a significant negative relationship between aid and private investment. More precisely, the point estimates imply that, in the long run, a one-percentage-point increase in the aid-to-GDP ratio decreases the private-investment-to-GDP ratio by about 0.27 to 0.34 percentage points. As noted earlier, possible channels are that, in the long run, aid crowds out private investment and/or undermines institutional quality by weakening accountability, encouraging rent seeking and corruption, and alleviating pressure to reform inefficient policies.

\section{[Table 3 about here]}

Given the small number of countries in this sample, we need, however, to ensure that the negative effect on private investment is not due to outliers. To this end, we reestimate the DOLS regression (with cross-sectionally demeaned data), excluding one country at a time from the sample. The estimated coefficients and their $t$-statistics are presented in Figure 1. Since the coefficients are fairly stable around -0.33 and always statistically significant at least at the five percent level, we conclude that the negative effect of aid on private investment is not the result of possible outliers.

[Figure 1 about here] 
Next, we examine whether the negative relationship between aid and private investment is robust to different forms or measures of aid. To this end, we re-estimate the DOLS regression (with demeaned data) using net ODA, excluding technical cooperation and food aid ( $A_{i t}^{\text {Financial }}$ ), invested aid by the government (aid-financed public investment) ( $\left.A_{i t}^{\text {Invested }}\right)$, and consumed aid ( $A_{i t}^{\text {Consumed }}$ ) in place of $A_{i t}$. The results are presented in Table 4. Regardless of which aid measure is used, the long-run relationship between aid and private investment remains negative and statistically significant. Particularly worth noting is that the coefficient on $A_{i t}^{\text {Invested }}$ is highly significant and of a similar magnitude as its counterpart in Table 3 (column 2). From this it can be concluded that the negative net effect of aid on private investment is primarily due to the presence of crowding out by aidfinanced public investment. The fact that the coefficient on $A_{i t}^{\text {Consumed }}$ is also significant and negative could suggest that aid also reduces private investment by weakening institutions and encouraging rent-seeking activities; these two mechanisms, however, seem of minor importance since the effect of consumed aid is smaller in magnitude than the effect of invested aid.

\section{[Table 4 about here]}

Finally, we examine whether the negative long-run relationship between aid and private investment is due to sample-selection bias. Sample-selection bias occurs when the selected sample is not random and thus not representative. A potential problem with our sample could be that it does not include any countries from Sub-Saharan Africa, except Kenya, and that it consists mainly of countries with low aid-to-GDP ratios, as discussed in Section III. We therefore re-estimate the DOLS regression (with demeaned data) for a second sample of 39 countries over the period from 1985 to 1999. In addition, we split this sample into three sub-samples: countries with aid inflows above five percent of GDP, countries with aid-to-GDP ratios between one and five percent, and countries with aid 
inflows below 0.1 percent. The resulting coefficients are listed in Table 5. They are all significant at least at the five percent level (although somewhat smaller than the estimates for the original sample), suggesting that the negative effect on private investment is not due to sample-selection bias. Moreover, given that all aid-coefficients in Table 5 have the same magnitude, it can be concluded that there are no significant differences in the effects of aid on private investment between highly aid-dependent countries, moderately aiddependent countries, and minimally aid-dependent countries. And lastly, the fact that the results for the period 1985 to 1999 (in Table 5) are qualitatively similar to those for the period 1970 to 1999 (in Table 3) suggests that the estimated negative coefficient on $A_{i t}$ is not sensitive to the sample period.

\section{[Table 5 about here]}

\section{Long-run causality}

Even though estimation by DOLS does not require the regressor(s) to be exogenous (and even though cointegration implies long-run Granger causality in at least one direction), we are interested in detecting the direction of long-run causality. Specifically, given that a negative correlation between $A_{i t}$ and $I_{i t}$ could also imply that countries in which private investment declined (for example, due to natural disasters or economic shocks) get more aid, it could well be that causality runs in both directions, that is, not only from aid to private investment but also from private investment to aid. Thus, the final step in our analysis is to examine the direction of causality.

Our causality test involves estimating a panel vector error correction model (VECM) given by 


$$
\left[\begin{array}{l}
\Delta I_{i t} \\
\Delta A_{i t}
\end{array}\right]=\left[\begin{array}{l}
c_{1 i} \\
c_{2 i}
\end{array}\right]+\sum_{j=1}^{p} \Gamma_{j}\left[\begin{array}{l}
\Delta I_{i t-j} \\
\Delta A_{i t-j}
\end{array}\right]+\left[\begin{array}{l}
a_{1} \\
a_{2}
\end{array}\right] e c_{i t-1}+\left[\begin{array}{l}
\varepsilon_{1 i t} \\
\varepsilon_{2 i t}
\end{array}\right]
$$

where $e c_{i t}=I_{i t}-\left[\hat{a}_{i}+\hat{\delta}_{i} t+\hat{\beta}_{i} A_{i t}\right]$ are the residuals from the DOLS long-run relations of the individual countries. A statistically significant coefficient on $e c_{i t-1}\left(a_{1,2}\right)$ implies long-run Granger causality from the independent to the dependent variable(s), where long-run Granger non-causality and weak exogeneity can be regarded as equivalent. Following Herzer (2008a, 2008b), we test for weak exogeneity by first imposing zero restrictions on the statistically insignificant short-run parameters $\left(\Gamma_{j}\right)$ and then using a conventional Wald test of the null hypothesis $a_{1,2}=0$. As in the previous section, we use both the raw and the cross-sectionally demeaned data for this purpose.

The Wald statistics and the corresponding $p$-values are presented in Table 6. As can be seen from the table, the unadjusted and demeaned data produce similar results. In both cases, the null hypothesis of weak exogeneity is rejected for both $I_{i t}$ and $A_{i t}$ at the one percent significance level. Thus, private investment is endogenous in the long run, implying that the estimates in the previous section reflect a causal long-run effect of aid on private investment, as expected. However, this long-run causality is bidirectional, suggesting that increased private investment also reduces (quite plausibly) the amount of aid given to a country.

[Table 6 about here]

\section{Conclusion}

This paper has examined the relationship between development aid and private investment in developing countries using panel cointegration and causality techniques that are 
specifically designed to deal with key problems (endogeneity and omitted variables) plaguing previous studies of the aid-private investment nexus. Our main result is that aid has a statistically significant negative effect on private investment. This result is robust to outliers, different measures or forms of aid, sample selection, and the sample period. Specifically, an important conclusion of our robustness analysis is that the effect of aid on private investment is qualitatively the same for highly aid-dependent countries, moderately aid-dependent countries, and less aid-dependent countries. Moreover, we find evidence that the negative effect of aid on private investment is primarily due to the crowding out of private investment by aid-financed public investment. Given that private investment must be considered as a key determinant of economic growth, our findings suggest that development aid does not exploit its full growth potential. Furthermore, our results show that the long-run causality between aid and private investment runs in both directions, specifically, larger amounts of aid lead to lower levels of private investment, and correspondingly, higher levels of private investment lead to lower inflows of aid.

If we find that aid has rather negative effects on private investment and that this is at least partly due to crowding out through public investment, then the implication can or should of course not be that aid is bad for private investment per se. It suggests rather that aid is clearly not used in a way that would generate optimal complementarities between public and private investment. This implies in turn that if aid were more systematically used for investment in infrastructure, research and development, improvements in the quality of institutions, and for a better skilled work force, private investment would likely respond positively to aid. This is consistent with the broader view that aid is effective if economic policies are good (Burnside and Dollar, 2000, 2004; Collier and Dollar, 2004). Another implication of our findings is that the link between aid and private investment can be strengthened if policy enhances the development of capital markets and it is accordingly 
less likely that public and private investors would compete for the same financial resources. Obviously, these conclusions are suggestive and need further investigation, but this is beyond the scope of this article.

\section{Acknowledgement}

We are grateful to two anonymous referees for excellent suggestions that considerably improved this paper.

\section{References}

Agénor, P.-R. and J. Montiel (2008) Development macroeconomics. 3rd edition. Princeton University Press, Princeton.

Agénor, P.-R., M.K. Nabli, T. Yousef and H.T. Jensen (2007) Labour market reforms, growth, and unemployment in labour-exporting countries in the Middle East and North Africa. Journal of Policy Modeling, 29, 277-309.

Aizenmann, J. and N.P. Marion (1993) Macroeconomic uncertainty and private investment. Economics Letters, 41, 207-210.

Alesina, A. and G. Tabellini (1989) External debt, capital flight, and political risk. Journal of International Economics, 27, 199-220.

Bleaney, M. and D. Greenaway (1993) Adjustment to external imbalance and investment slumps in developing countries. European Economic Review, 37, 577-585.

Boone, P. (1996) Politics and the effectiveness of foreign aid. European Economic Review, 40, 289-329.

Bräutigam, D.A. and S. Knack (2004) Foreign aid, institutions, and governance in subSaharan Africa. Economic Development and Cultural Change, 52, 255-285. 
Breitung, J. (2005) A parametric approach to the estimation of cointegrating vectors in panel data. Econometric Reviews, 24, 151-173.

Burnside, C. and D. Dollar (2000) Aid, policies and growth. American Economic Review, 90, $847-868$.

Burnside, C. and D. Dollar (2004) Aid, policies, and growth: revisiting the evidence. World Bank Policy Research Working No. 3251.

Collier, P. and J. Dehn (2001) Aid, shocks, and growth. World Bank Policy Research Paper No. 2688.

Collier, P. and D. Dollar (2004) Development effectiveness: what have we learnt? Economic Journal, 114, F244-F271.

Commission for Africa (2005) Our common interest. Report of the Commission for Africa. Commission for Africa, London.

Crowder, W.J. and P. de Jong (2010) Does investment lead to greater output? A panel error-correction model analysis. Applied Economics, forthcoming.

Daalgard, C.-H. and H. Hansen (2001) On aid, growth, and good policies. Journal of Development Studies, 37, 17-41.

Daalgard, C.-H., H. Hansen and F. Tarp (2004) On the empirics of foreign aid and growth. Economic Journal, 114, 191-216.

Dalgaard, C.-J. and L. Erickson (2009) Reasonable expectations and the First Millennium Development Goal: how much can aid achieve? World Development, 37, 1170-1181.

Devarajan, S., W. Easterly and H. Pack (2003) Low investment is not the constraint on African development. Economic Development and Cultural Change, 51, 547-71.

Djankov, S., J.G. Montalvo, J.G. and M. Reynal-Querol (2008). The course of aid. Journal of Economic Growth, 13, 169-194. 
Dollar, D. and W. Easterly (1999) The search for the key: aid, investment and policies in Africa. Journal of African Economies, 8, 546-577.

Drine, I., and C. Rault (2003) Do panel data permit the rescue of the Balassa-Samuelson hypothesis for Latin American countries? Applied Economics, 35, 351-359.

Easterly, W., R. Levine and D. Roodman (2004) Aid policies and growth: comment, American Economic Review, 94, 774-780.

Economides, G., S. Kalyvitis and A. Phillippopoulos (2008) Does foreign aid distort incentives and hurt growth? Theory and evidence from 75 aid-recipient countries. Public Choice, 134, 463-488.

Everhart, S.S. and M.A. Sumlinski (2001) Trends in private investment in developing countries, statistics for 1970-2000 and the impact on private investment of corruption and the quality of public investment. International Finance Corporation Discussion Paper No. 44, World Bank, Washington D.C.

Gomanee, K., S. Girma and O. Morrissey (2005) Aid and growth in sub-Saharan Africa: accounting for transmission mechanisms. Journal of International Development, 17, $1055-1076$.

Greene, J. and D. Villanueva (1991) Private investment in developing countries. IMF Staff Papers, 38, 33-58.

Griffin, K. (1970) Foreign capital, domestic savings, and economic development. Bulletin of the Oxford University Institute of Economics and Statistics, 32, 99-112.

Guillaumont, P. and L. Chauvet (2001) Aid and performance: a reassessment. Journal of Development Studies, 37, 66-92.

Hadjimichael, M.T., D. Gura, M. Mühleisen, R. Nord and E.M. Ucer (1995) Sub-Saharan Africa: growth, savings, and investment, 1986-93. International Monetary Fund Occasional Paper No. 118, International Monetary Fund, Washington D.C. 
Herzer, D. (2008a) The long-run relationship between outward FDI and domestic output: evidence from panel data. Economics Letters, 100, 146-149.

Herzer, D. (2008b) The causal relationship between domestic and outward foreign investment: evidence for Italy. Applied Financial Economics Letters, 4, 307-310.

Herzer, D. and O. Morrissey (2009) The long-run effect of aid on domestic output. CREDIT Research Paper 09, 01. Centre for Research in Economic Development and International Trade, Nottingham.

Hodler, R. (2007) Rent seeking and aid effectiveness. International Tax and Public Finance, 14, 525-541.

Holly, S., M.H. Pesaran and T. Yamagata (2010) A spatio-temporal model of house prices in the US. Journal of Econometrics, forthcoming.

Im, K.S., M.H. Pesaran and Y. Shin (2003) Testing for unit roots in heterogeneous panels. Journal of Econometrics, 115, 53-74.

Johansen, S. (1988) Statistical analysis of cointegrating vectors. Journal of Economic Dynamics and Control, 12, 231-254.

Johansen, S. (2000) Modelling of cointegration in the vector autoregressive model. Economic Modelling, 17, 359-73.

Kao, C. and M. Chiang (2000) On the estimation and inference of a cointegrated regression in panel data. Advances in Econometrics, 15, 179-222.

Khan, M. and C. M. Reinhart (1990) Private investment and economic growth in developing countries. World Development, 18, 19-27.

Knack, S. (2001) Aid dependence and the quality of governance. Southern Economic Journal, 68, 310-329. 
Larrain, F. and R. Vergara (1993) Investment and macroeconomic adjustment: the case of East Asia. In L. Serven and A. Solimano (eds.) Striving for growth after adjustment. World Bank, Washington D.C.

Larsson, R., J. Lyhagen and M. Löthegren (2001) Likelihood-based cointegration tests in heterogeneous panels. Econometrics Journal, 4, 109-142.

MacKinnon, J.G., A.A. Haug and L. Michelis (1999) Numerical distribution functions of likelihood ratio tests for cointegration. Journal of Applied Econometrics, 14, 563577.

Madalla, G.S. and S. Wu (1999) A comparative study of unit root tests with panel data and a new simple test. Oxford Bulletin of Economics and Statistics, Special Issue, 631652.

Mahdavi, S. (1990) The effects of foreign resource inflows on composition of aggregate expenditure in developing countries: a seemingly unrelated model. Kyklos, 43, 111137.

Maren, M. (1997) The road to hell: the ravaging effects of foreign aid and international charity. New York: Free Press.

McGillivray, M. and O. Morrissey (2004) Fiscal effects of aid. In Addison, T. and A. Roe (eds.) Fiscal policy for development: poverty, reconstruction, and growth. Palgrave Macmillan for UNU-Wider: Basingstoke.

McGillivray, M., S. Feeny, N. Hermes and R. Lensink (2006) Controversies over the impact of development aid: it works; it doesn't; it can, but that depends. Journal of International Development, 18, 1031-1050.

Mitra, P. (2006) Has government investment crowded out private investment in India? American Economic Review, 96, 337-341. 
Mlambo, K. and T.W. Oshikoya (2001) Macroeconomic factors and investment in Africa. Journal of African Economies, 10, 12-47.

Mosley, P., J. Hudson and S. Horrel (1987) Aid, the public sector and the market in less developed countries. Economic Journal, 97, 616-641.

Nazmi, N. and M.D. Ramirez (1997) Public and private investment and economic growth in Mexico. Contemporary Economic Policy, 15, 65-75.

Pagan, A. (1984) Econometric issues in the analysis of regressions with generated regressors. International Economic Review, 25, 221-247.

Pedroni, P. (1999) Critical values for cointegration tests in heterogeneous panels with multiple regressors. Oxford Bulletin of Economics and Statistics, 61, 653-670.

Pesaran, M.H. (2006) Estimation and inference in large heterogeneous panels with a multifactor error structure. Econometrica, 74, 967-1012.

Pesaran, M.H. (2007) A simple panel unit root test in the presence of cross-section dependence. Journal of Applied Econometrics, 22, 265-312.

Pritchett, L. (1996) Mind your p's and q's. The cost of public investment is not the value of public capital. World Bank Policy Research Working Paper No. 1660. World Bank, Washington D.C.

Rajan, R.R. and A. Subramanian (2007) Does aid affect governance? American Economic Review, 97, 322-327.

Rajan, R.R. and A. Subramanian (2008) Aid and growth: what does the cross-country evidence really show? Review of Economics and Statistics, 90, 643-665.

Rama, M. (1993) Empirical investment equations in developing countries. In L. Serven and A. Solimano (eds.) Striving for growth after adjustment. World Bank, Washington D.C. 
Ramirez M.D. (2000) The impact of public investment on private investment spending in Latin America: 1980-1995. Atlantic Economic Journal, 28, 210-225.

Rodrik, D. (1991) Policy uncertainty and private investment in developing countries. Journal of Development Economics, 36, 229-242.

Servén, L. and A. Solimano (1993) Private investment and macroeconomic adjustment: a survey. In L. Serven and A. Solimano (eds.) Striving for growth after adjustment. World Bank, Washington D.C.

Snyder, D.W. (1996) Foreign aid and private investment in developing economies. Journal of International Development, 8, 735-745.

Weisskopf, T. (1972) The impact of foreign capital inflows on domestic savings in underdeveloped countries. Journal of International Economics, 2, 25-38.

World Bank (1998) Assessing aid: what works and what doesn't, and why? World Bank, Oxford: Oxford Univ. Press. 
Table 1. Panel unit root tests

\begin{tabular}{lccc}
\hline Variable & Deterministic terms & IPS statistics & CIPS statistics \\
\hline Levels & & & \\
$I_{i t}$ & $c, t$ & -1.52 & -1.80 \\
$A_{i t}$ & $c, t$ & -0.10 & -1.98
\end{tabular}

First differences
$\Delta I_{i t}$
$C$
$-6.39 * *$
$-2.51 * *$
$\Delta A_{i t}$
C $\quad-6.07 * *$
$-2.37 * *$

Notes: $c(t)$ indicates that we allow for different intercepts (and time trends) for each country. Three lags were selected to adjust for autocorrelation. The IPS statistic is distributed as $\mathrm{N}(0,1)$. The relevant $5 \%(1 \%)$ critical value for the CIPS statistics is -2.67 (-2.83) with an intercept and a linear trend, and -2.15 (-2.32) with an intercept. ** denote significance at the $1 \%$ level.

\section{Table 2. Panel cointegration tests}

\begin{tabular}{lcc}
\hline & \multicolumn{2}{c}{ Cointegration rank } \\
\cline { 2 - 3 } & \multicolumn{1}{c}{$r=0$} & $r=1$ \\
\hline Standardized panel trace statistics & $4.34^{* *}$ & -0.61 \\
Fisher statistics & $75.71^{* *}$ & 29.69 \\
\hline CIPS statistic & \multicolumn{2}{c}{$-2.18^{*}$} \\
Panel ADF statistic & \multicolumn{2}{c}{$-4.87^{* *}$} \\
Group ADF statistic & \multicolumn{2}{c}{$-5.40^{* *}$} \\
\hline
\end{tabular}

Notes: The panel trace statistic, the panel ADF statistic, and the group ADF statistic are distributed as $\mathrm{N}(0$, 1). The Fisher statistic is distributed as $\chi^{2}$ with $2 \times \mathrm{N}$ degrees of freedom. It has a critical value of 58.62 (51) at the $1 \%(5 \%)$ level. The relevant $5 \%$ (1\%) critical value for the CIPS statistic is $-2.15(-2.32)$. The number of lags was determined by the Schwarz criterion with a maximum of three lags. $* *(*)$ indicate a rejection of the null hypothesis of no cointegration at the $1 \%(5 \%)$ level.

Table 3. DOLS estimates of the long-run effect of aid on private investment for the period from 1970 to 1999 (coefficients on $A_{i t}$ )

\begin{tabular}{cc}
\hline Raw data & Demeaned data \\
\hline$-0.265^{*}$ & $-0.338^{* *}$ \\
$(-2.11)$ & $(-2.69)$ \\
\hline
\end{tabular}

Notes: The dependent variable is $I_{i t} . t$-statistics in parenthesis. ${ }^{* *}(*)$ indicate significance at the $1 \%(5 \%)$ level. The DOLS regression was estimated with one lead and lag. 
Table 5. Estimates of the long-run impact of aid on private investment using different samples over the period from 1985 to 1999

\begin{tabular}{lccc}
\hline & $\begin{array}{c}\text { Coefficients on } \\
A_{i t}\end{array}$ & $t$-statistics & $\begin{array}{c}\text { Number of countries } \\
\text { in the sample }\end{array}$ \\
\hline $\begin{array}{l}\text { Total sample } \\
\text { Countries with aid inflows above 5 }\end{array}$ & $-0.170^{* *}$ & -3.00 & 39 \\
percent of GDP & $-0.165^{*}$ & -2.32 & 10 \\
$\begin{array}{l}\text { Countries with aid-to-GDP ratios } \\
\text { between 1 and 5 percent }\end{array}$ & $-0.182 * *$ & -2.83 & 13 \\
$\begin{array}{l}\text { Countries with aid inflows below } \\
0.1 \text { percent }\end{array}$ & $-0.168 * *$ & -3.22 & 16 \\
\hline $\begin{array}{l}\text { Notes: } * *(*) \text { indicate significance at the 1\% (5\%) level. The DOLS regression was estimated with one lead } \\
\text { and lag. }\end{array}$
\end{tabular}

Table 6. Weak exogeneity tests / long-run causality tests

\begin{tabular}{lcc}
\hline $\begin{array}{l}\text { Variable } \\
\text { Coefficient })\end{array}$ & $\begin{array}{c}I_{i t} \\
\left(\alpha_{1}\right)\end{array}$ & $\begin{array}{c}A_{i t} \\
\left(\alpha_{2}\right)\end{array}$ \\
\hline $\begin{array}{l}\text { Raw data } \\
\chi^{2}(1) \\
(p \text {-values })\end{array}$ & $\begin{array}{l}101.97 \\
(0.000)\end{array}$ & $\begin{array}{c}(0.005) \\
\end{array}$ \\
$\begin{array}{l}\text { Demeaned data } \\
\chi^{2}(1) \\
(p \text {-values })\end{array}$ & $\begin{array}{l} \\
\text { Notes: The number of degrees of freedom } v \text { in the standard } \chi^{2}(v) \text { tests corresponds to the number of zero } \\
\text { restrictions. The models were estimated with up to three lags. }\end{array}$
\end{tabular}


Fig. 1. DOLS estimation with single country excluded from the sample
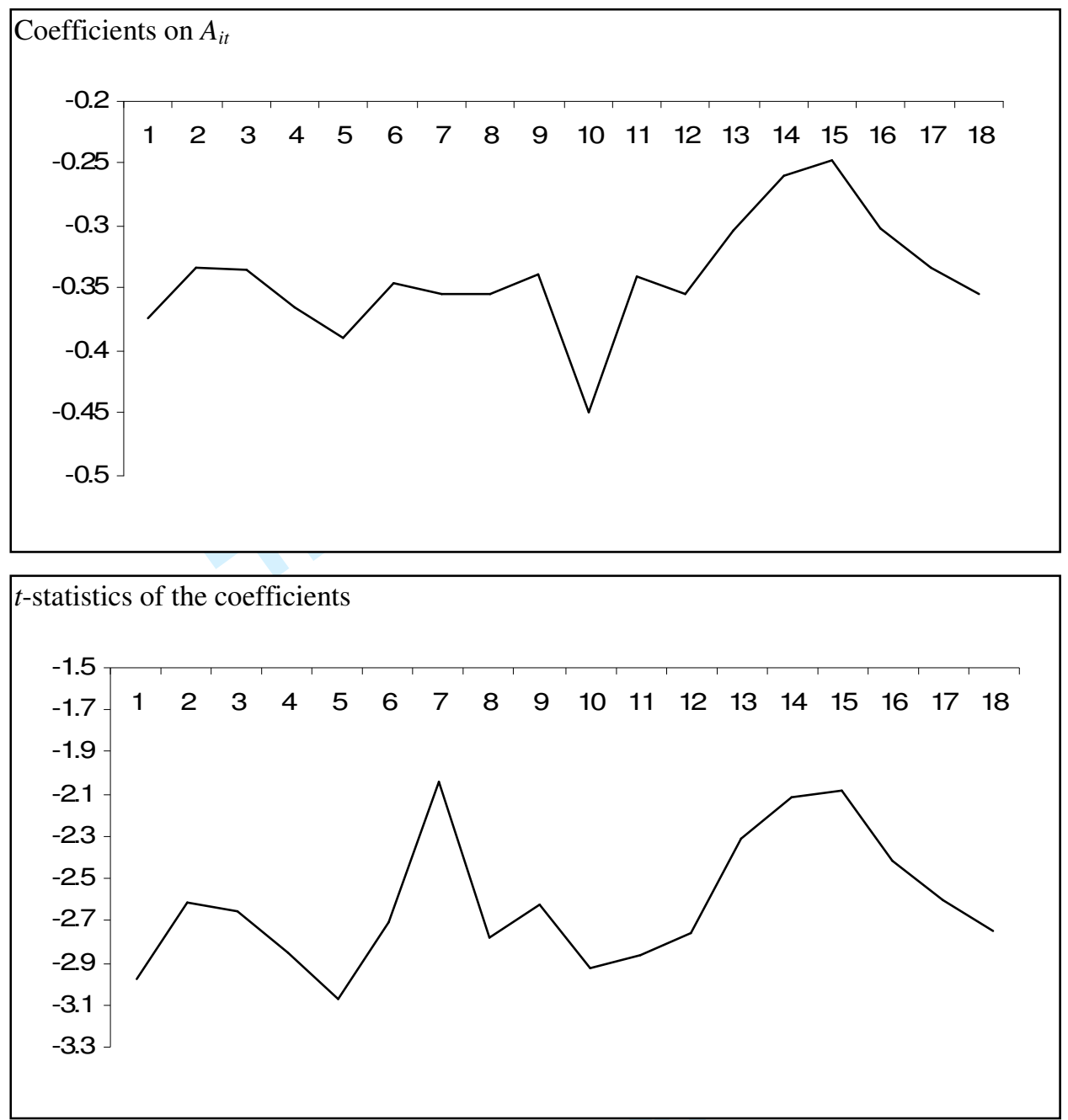